\title{
Generation of a panel of antibodies against proteins encoded on human chromosome 21
}

\author{
Frances K Wiseman', Olivia Sheppard', Jacqueline M Linehan', Sebastian Brandner', Victor LJ Tybulewicz², \\ Elizabeth MC Fisher ${ }^{1 *}$
}

\begin{abstract}
Background: Down syndrome (DS) is caused by trisomy of all or part of chromosome 21. To further understanding of DS we are working with a mouse model, the Tc1 mouse, which carries most of human chromosome 21 in addition to the normal mouse chromosome complement. This mouse is a model for human DS and recapitulates many of the features of the human syndrome such as specific heart defects, and cerebellar neuronal loss. The Tc1 mouse is mosaic for the human chromosome such that not all cells in the model carry it. Thus to help our investigations we aimed to develop a method to identify cells that carry human chromosome 21 in the Tc1 mouse. To this end, we have generated a panel of antibodies raised against proteins encoded by genes on human chromosome 21 that are known to be expressed in the adult brain of Tc1 mice

Results: We attempted to generate human specific antibodies against proteins encoded by human chromosome 21. We selected proteins that are expressed in the adult brain of Tc1 mice and contain regions of moderate/low homology with the mouse ortholog. We produced antibodies to seven human chromosome 21 encoded proteins. Of these, we successfully generated three antibodies that preferentially recognise human compared with mouse SOD1 and RRP1 proteins on western blots. However, these antibodies did not specifically label cells which carry a freely segregating copy of Hsa21 in the brains of our Tc1 mouse model of DS.

Conclusions: Although we have successfully isolated new antibodies to SOD1 and RRP1 for use on western blots, in our hands these antibodies have not been successfully used for immunohistochemistry studies. These antibodies are freely available to other researchers. Our data high-light the technical difficulty of producing species-specific antibodies for both western blotting and immunohistochemistry.
\end{abstract}

\section{Background}

Down syndrome (DS) is the most common genetic cause of intellectual disability and is also associated with a number of other medical problems including heart defects, early onset Alzheimer's disease and leukaemia [1]. DS is caused by trisomy of human chromosome 21 and is a complex genetic disorder in which the phenotype arises from abnormal dosage of otherwise normal genes.

In order to investigate the relationship between phenotype and causative dosage sensitive genes in DS, we created the Tc1 mouse strain which carries a freely segregating copy of human chromosome 21 (Hsa21) in

\footnotetext{
* Correspondence: e.fisher@prion.ucl.ac.uk

'Department of Neurodegenerative Disease, UCL Institute of Neurology,

Queen Square, London WC1N 3BG, UK

Full list of author information is available at the end of the article
}

addition to a full complement of mouse chromosomes [2]. There are deletions in this Hsa21 [2] but at least $83 \%$ of the human genes are present in three copies (one human, two endogenous mouse homologs). Therefore, Tc1 mice are trisomic for the majority of genes on Hsa21 and several different investigations have shown they do indeed have phenotypes which are strikingly similar to those found in individuals with DS [2-5].

However, the Tc1 mouse is mosaic for Hsa21, owing to stochastic loss of the human chromosome in cells after fertilisation. Thus the mice have some cells that contain Hsa21 and some that are euploid, which have the normal mouse chromosome complement. The degree of mosaicism differs between tissues and is reported to vary between individual mice; in one survey carried out by genomic quantitative-PCR, on 8 animals, between 7 and $77 \%$ of cells in the brain of Tc1 mice

\section{() Biomed Central}


carried the Hsa21 (mean 53\%) [2]. When chromosome 21 content was assessed directly by fluorescence in situ hybridisation with a human specific probe on metaphase spreads of Tc1 brain cells, between 36 and $94 \%$ of the cells carried Hsa21 [2]. Between 2-4\% of people with DS also have a mixture of euploid and trisomic cells [6,7]. A low proportion of trisomic cells in these individuals is associated with a reduced severity and incidence of DS associated phenotypes [8]. Additionally, people without DS have also been reported to be mosaic for Hsa21 trisomic cells, in particular individuals with Alzheimer's disease have been reported to have an elevated number of Hsa21 trisomic cells within their brains [9-11]. The phenotypic consequences of these observations have yet to be fully explored.

A study of Hsa21 mosaicism in the Tc1 mouse model may provide insight into these issues. In particular, variability in DS associated phenotypes observed in the Tc1 mouse model may result in part from variation in the number of Hsa21-containing cells in specific tissues and/or cell types. For example, only $73 \%$ of Tc1 mice show heart defects at E14.5, whereas the remaining 27\% of their genetically identical, Hsa21 positive, littermates do not [2]. This may be due to variable penetrance of the effects of the dosage-sensitive Hsa21 genes, and/or it may be due to mosaicism in the hearts of these animals. In addition, if we could identify Hsa21 positive cells in vivo this may help us investigate the effects of Hsa21 trisomy at the cellular level. Therefore, in an effort to determine which cells in Tc1 mice carry Hsa21 and thus measure levels of mosaicism, we generated antibodies against proteins encoded by $\mathrm{Hsa} 21$ that do not cross react with mouse homologues. We focussed our study on proteins expressed in brain as this is our primary organ of interest.

We successfully generated antibodies that preferentially recognised human but not mouse forms of Hsa21encoded proteins as shown by western blotting. However these antibodies were not compatible with immunohistochemical methods and therefore could not be used to identify individual cells that carry Hsa21. We note that these antibodies are available for other interested laboratories to use.

\section{Results}

\section{Choice of candidate proteins}

We aimed to generate novel human-specific antibodies raised against proteins encoded on Hsa21 to identify Hsa21 positive cells in our Tc1 mouse model of DS. Our principal goal was to produce a human-specific antibody that did not react with mouse proteins and that was highly expressed in the adult brain as this is our main organ of interest. We used published data and online resources (NCBI- Gene Expression Nervous
System Atlas, Affymetrix Symatlas/BioGPS) to identify candidate genes that were reported to be expressed widely in the brain (Table 1). To avoid generating antibodies against hypothetical proteins we prioritised targets for which there was evidence of a functional protein. Regions of low homology between the human protein and the mouse homologue where then identified by performing Clustal W alignments. In the case of one gene, $A D A R B 1$, an exon unique to humans was identified.

The secondary structure and accessibility of these low homology regions were modelled using PHD and PROF programmes that were accessed from the Predict Protein website http://cubic.bioc.columbia.edu/predictprotein/. Additionally, the regions were checked against published protein structures to confirm accessibility. The antigenicity of sequences was also estimated using the method of Jameson and Wolf which combines indicators of hydropathy, secondary structure and structural flexibility [12]. Candidate sequences were also checked for consensus sequences for posttranslational modifications including signal sequence cleavage, glycosylation, phosphorylation, and myristoylation using algorithms available from the Predict Protein website [13,14].

Candidate regions that were predicted to be accessible, not post-translationally modified, and exhibited a moderate/high antigenicity index, were checked for similarity with mouse proteins using blastp http://blast.ncbi.nlm. nih.gov/Blast.cgi. Those that were highly similar to mouse proteins were discarded as candidates. Ten candidate polypeptide sequences in eight candidate proteins were identified: an RNA editase (ADARB1), a Golgi-resident galactosyltransferase (B3GAL-T5) (two sequences), a potential neurodevelopmental protein (DOPEY2), the Golgi enzyme formimidoyltransferase-cyclodeaminase (FTCD), an RNA processing enzyme (RRP1) (two sequences), superoxide dismutase 1 (SOD1), a cation membrane channel (TRPM2) and a histone deubiquitinase (USP16).

Expression of $A D A R B 1, B 3 G A L-T 5, D O P E Y 2, F T C D$, RRP1, TRPM2 and USP16 was investigated by RT-PCR. Total RNA was isolated from adult Tc1 mouse brain and non-transchromosomic littermate control brain, and subjected to RT-PCR $(\mathrm{n}=5)$. Significant expression of FTCD could not be detected in human or Tc1 brain (Figure 1D). Therefore the two identified FTCD polypeptide sequences were discarded as potential candidates against which to raise an antibody. The expression of the other genes of interest was confirmed in the Tc1 brain (Figure 1). Elevated expression of SOD1 in the Tc1 brain had been previously demonstrated by western blot [2].

Production, conjugation of the selected peptides to Keyhole limpet haemocyanin (KHL) and injection of the 
Table 1 List of Hsa21 genes present in the Tc1 mouse that are expressed in adult brain

\begin{tabular}{|c|c|c|}
\hline $\begin{array}{l}\text { Hsa21 } \\
\text { encoded } \\
\text { Protein }\end{array}$ & Evidence of expression in brain & Candidate regions and/or reasons for discontinuation \\
\hline $\begin{array}{l}\text { HSPA13/ } \\
\text { STCH }\end{array}$ & Ubiquitous expressed [17] & No human specific region \\
\hline NRIP1 & Expressed in mouse brain [18] and Gensat images 24262 and 24263) & No human specific region \\
\hline$\overline{\text { USP25 }}$ & $\begin{array}{l}\text { Basal expression in all human tissues but high expression only in fetal } \\
\text { brain and adult testis }[19,20]\end{array}$ & N/A \\
\hline NCAM2 & Expression in adult human brain [21] & No human specific region \\
\hline MRPL39 & Expressed in adult mouse and human brain $[18,21]$ & $\begin{array}{l}\text { Possible region (aa 1-42 } \\
\text { MEALAMGSRALRLWLVAPGGGIKWRFIATSSASQLSPTELTE) is } \\
\text { putative mitochondrial targeting sequence [13] }\end{array}$ \\
\hline JAM2 & Expression in brain restricted to vascular endothelial cells $[22,23]$ & N/A \\
\hline GABPA & Expression in adult mouse brain [18] & No human specific region \\
\hline ADAMTS5 & Expression in adult mouse brain restricted to Schwann cells [24] & N/A \\
\hline ADAMTS1 & Expression in adult rat brain restricted to neuron subpopulation [25] & N/A \\
\hline USP16 & Expressed in human and mouse brain $[18,21]$ & 1 region used for antibody generation (see table 2 ). \\
\hline $\begin{array}{l}\text { CCT8/ } \\
\text { CCTQ }\end{array}$ & Expressed in mouse brain $[18,26,27]$ & No human specific region \\
\hline$\overline{\mathrm{BACH} 1}$ & Expressed in adult mouse and human brain $[21,28]$ & $\begin{array}{l}\text { Possible region (aa 676-716 } \\
\text { RPPAVLPPCARGNSEPGYARGQESQQMSTATSEQAGPAEQCR) } \\
\text { contains a putative disulphide bond }\end{array}$ \\
\hline GRIK1 & Expressed in adult mouse and human brain $[29,30]$ & No human specific region \\
\hline TIAM1 & Expression in adult mouse and human brain [18] & No human specific region \\
\hline SOD1 & $\begin{array}{l}\text { Expressed in human and mouse brain } \\
{[31,32]}\end{array}$ & 1 region used for antibody generation (see table 2) \\
\hline CBR1 & Expressed in human adult and fetal brain $[21,33]$ & No human specific region \\
\hline$\overline{\mathrm{CBR3}}$ & Expressed in human adult brain [34] & $\begin{array}{l}\text { Possible region (aa } 236-242 \text { GKDSI) similarity with mouse } \mathrm{Hy}-3 \\
\text { and DNA isomerase } 1\end{array}$ \\
\hline $\begin{array}{l}\text { DOPEY2/ } \\
\text { C21orf5 }\end{array}$ & $\begin{array}{l}\text { Expression in cortex, cerebellum, and hippocampus in adult, } \\
\text { widespread expression in embryonic and fetal brain [35-38] }\end{array}$ & $\begin{array}{l}1 \text { region used for antibody generation (see table } 2) \text {, } \\
2^{\text {nd }} \text { region (aa. 671-684 LAANDSERKNSWEP) contains N- } \\
\text { glycosylation site }\end{array}$ \\
\hline$\overline{M O R C 3}$ & Expressed in adult human brain [21] & $\begin{array}{l}\text { Possible region cross (aa 665-696 } \\
\text { DAVILPSCVEAEAKIHETQETTDKSADDAGC) similar to mouse } \\
\text { Btnl2 and KIF21B }\end{array}$ \\
\hline$\overline{\mathrm{SIM} 2}$ & $\begin{array}{l}\text { Long isoform expressed in adult mouse brain particularly expressed in } \\
\text { amygdala, hippocampus and thalamus, expression in embryonic and } \\
\text { fetal brain, short isoform not expressed in adult brain [39-41] }\end{array}$ & $\begin{array}{l}\text { Possible region (long form aa 613-624 GAAPAASGLAC) } \\
\text { predicted low antigenicity }\end{array}$ \\
\hline $\begin{array}{l}\text { DSCR3/ } \\
\text { DCRA }\end{array}$ & Expressed in human and mouse adult brain $[21,42]$ & No human specific region \\
\hline DYRK1A & Expression in adult mouse and human brain [43-45] & No human specific region \\
\hline $\begin{array}{l}\text { KCNJ6/ } \\
\text { GIRK2 }\end{array}$ & Expressed in subset of cells throughout mouse brain [46-48] & N/A \\
\hline ETS2 & Expressed in human and mouse brain $[18,49]$ & No human specific region \\
\hline $\begin{array}{l}\text { PSMG1/ } \\
\text { DSCR2 }\end{array}$ & Expressed in adult mouse brain $[18,50]$ & No human specific region \\
\hline B3GALT5 & Expressed in adult human and mouse brain $[18,51]$ & 1 region used for antibody generation (see table 2) \\
\hline $\begin{array}{l}\text { PCP4/PEP- } \\
19\end{array}$ & $\begin{array}{l}\text { Expressed restricted to cerebellum and olfactory bulb in adult mouse } \\
\text { and caudate-putamen in human [52-54] }\end{array}$ & No human specific region \\
\hline DSCAM & Expressed in adult mouse and human brain $[55,56]$ & No human specific region \\
\hline BACE2 & $\begin{array}{l}\text { Expressed in adult mouse and human brain but at low levels } \\
{[18,57-60]}\end{array}$ & $\begin{array}{l}\text { Human specific region of } 396 \text { aa isoform (aa380-396 } \\
\text { LQCLKFPGLSQQRM) predicted low antigenicity }\end{array}$ \\
\hline UMODL1 & $\begin{array}{l}\text { Expression in embryonic mouse brain restricted to olfactory and } \\
\text { vomeronasal neurons [61] }\end{array}$ & N/A \\
\hline $\mathrm{ABCG} 1$ & Expressed in adult human and mouse brain $[21,62,63]$ & No human specific region \\
\hline
\end{tabular}


Table 1 List of Hsa21 genes present in the Tc1 mouse that are expressed in adult brain (Continued)

\begin{tabular}{|c|c|c|}
\hline WDR4 & $\begin{array}{l}\text { Basal expression in adult tissues only high expression in fetal tissues } \\
\text { [64] }\end{array}$ & N/A \\
\hline $\begin{array}{l}\text { PKNOX1/ } \\
\text { PREP1 }\end{array}$ & Expressed in adult human and mouse brain $[65,66]$ & No human specific region \\
\hline CBS & $\begin{array}{l}\text { Expressed in astrocytes and Bergmann glial cells only in adult mouse } \\
\text { brain [67] }\end{array}$ & N/A \\
\hline U2AF1 & Expressed in adult mouse and human brain $[21,68]$ & No human specific region \\
\hline CSTB & $\begin{array}{l}\text { Expressed in adult mouse and human brain (astrocytes and neurons) } \\
{[18,21,69]}\end{array}$ & No human specific region \\
\hline NNP1/RRPIB & Ubiquitously expressed in all human tissues $[21,70]$ & 2 regions used for antibody generation (see table 2) \\
\hline AGPAT3 & Expressed in adult mouse brain [71] & No human specific region \\
\hline $\begin{array}{l}\text { TRAPPC1/ } \\
\text { TMEM1 }\end{array}$ & Expressed in adult human brain [21] & No human specific region \\
\hline $\begin{array}{l}\text { PWP2/ } \\
\text { PWP2H } \\
\end{array}$ & Ubiquitously expressed in human adult tissue [72] & No human specific region \\
\hline$\underline{\mathrm{PFKL}}$ & Expressed in adult brain $[21,73]$ & No human specific region \\
\hline TRPM2 & $\begin{array}{l}\text { Expressed in human and mouse brain also in microglia cell lines and } \\
\text { cultured neurons [74-77] }\end{array}$ & 1 region used for antibody generation (see table 2 ) \\
\hline PTTG1IP & Expressed in human brain $[21,78]$ & $\begin{array}{l}1 \text { possible region (aa 1-29 } \\
\text { MAPGVARGPTPYWRLRLGGAALLLLLIPV) putative signal } \\
\text { sequence [14] }\end{array}$ \\
\hline $\begin{array}{l}\text { ADARB1/ } \\
\text { RED1 }\end{array}$ & Expressed in adult mouse and human brain [79-82] & 1 region used for antibody generation (see table 2) \\
\hline FTCD & $\begin{array}{l}\text { Expressed in fetal human brain and in numerous mammalian cells } \\
\text { types }[83,84]\end{array}$ & $\begin{array}{l}2 \text { possible human specific regions (long isoform aa } 423-446 \\
\text { GGPTGGSEAGSLCAADAGGDGGLA and aa 465-495 } \\
\text { PPGGQSPGDGRWWRIFQRAHQPEGHHRRGI) }\end{array}$ \\
\hline$\underline{\text { LSS }}$ & Expressed in adult mouse brain [18] & No human specific region \\
\hline S100Beta & $\begin{array}{l}\text { Expression in adult mouse and human brain (particularly astrocytes } \\
\text { and spinal, medullar, pontine and deep cerebellar neurons) }[18,21,85]\end{array}$ & No human specific region \\
\hline PRMT2 & Expressed in human adult brain $[21,86]$ & No human specific region \\
\hline
\end{tabular}

Evidence for expression in adult brain is listed in column two, including evidence for restriction of expression to a subset of cells. In column three candidate regions with moderate or low homology with their mouse ortholog are identified and any rational for not using the region to attempt to generate an antibody is described.

KHL-peptides into New Zealand Rabbits was undertaken (21st Century Biochemicals). In the case of B3GALT5 and RRP1 a mixture of two peptides were injected into each rabbit (Table 2). Sera isolated from the rabbits after the fifth, sixth and seventh KHL-peptide boost was affinity purified against the peptide. Sera from the rabbits challenged with B3GAL-T5 and RRP1 peptides were affinity purified against both peptides separately.

\section{Antibodies that recognise a Tc1 Hsa21 specific protein RRP1}

One of the anti-RRP1 antibodies (9644-B), which was purified against peptide $\mathrm{B}$, recognised a $50 \mathrm{kDa}$ band on western blots of Tc1 total brain proteins; consistent with the predicted molecular weight of RRP1 (Figure 2A). A similar band was not observed in non-transchromosomic control mice, indicating that this antibody may specifically react with human RRP1. RRP1 peptide sequence $B$ is unique to the human protein and is not found in mouse RRP1. In addition to the Tc1 specific band a number of weaker additional bands were observed in samples of Tc1 and non-Tc1 total brain proteins. These are likely to represent non-specific interaction of the polyclonal antibody with other brain proteins. Despite the relative specificity of the 9644-B antibody on western blot, a similar pattern and intensity of staining was observed on Tc1 and non-transchromosomic control mouse whole brain sections; intracellular staining was observed through-out the brain in both Tc1 and control non-transchromosomic mice (Figure $3 \mathrm{~A}$ and $3 \mathrm{~B})$. Therefore, although $9644-\mathrm{B}$ may be a suitable antibody for western blot studies of RRP1, it cannot be used to identify $\mathrm{Hsa} 21$ positive cells in the brains of Tc1 mice.

Affinity purified antibody raised against RRP1 peptide $B$ purified from the second rabbit (9643-B) did not recognise a Tc1 specific band (Figure $2 \mathrm{~B}$ ). A $50 \mathrm{kDa}$ protein was weakly detected using this antibody in samples of Tc1 and control mouse brain; however, peptide $B$ does not share any homology with mouse RRP1 


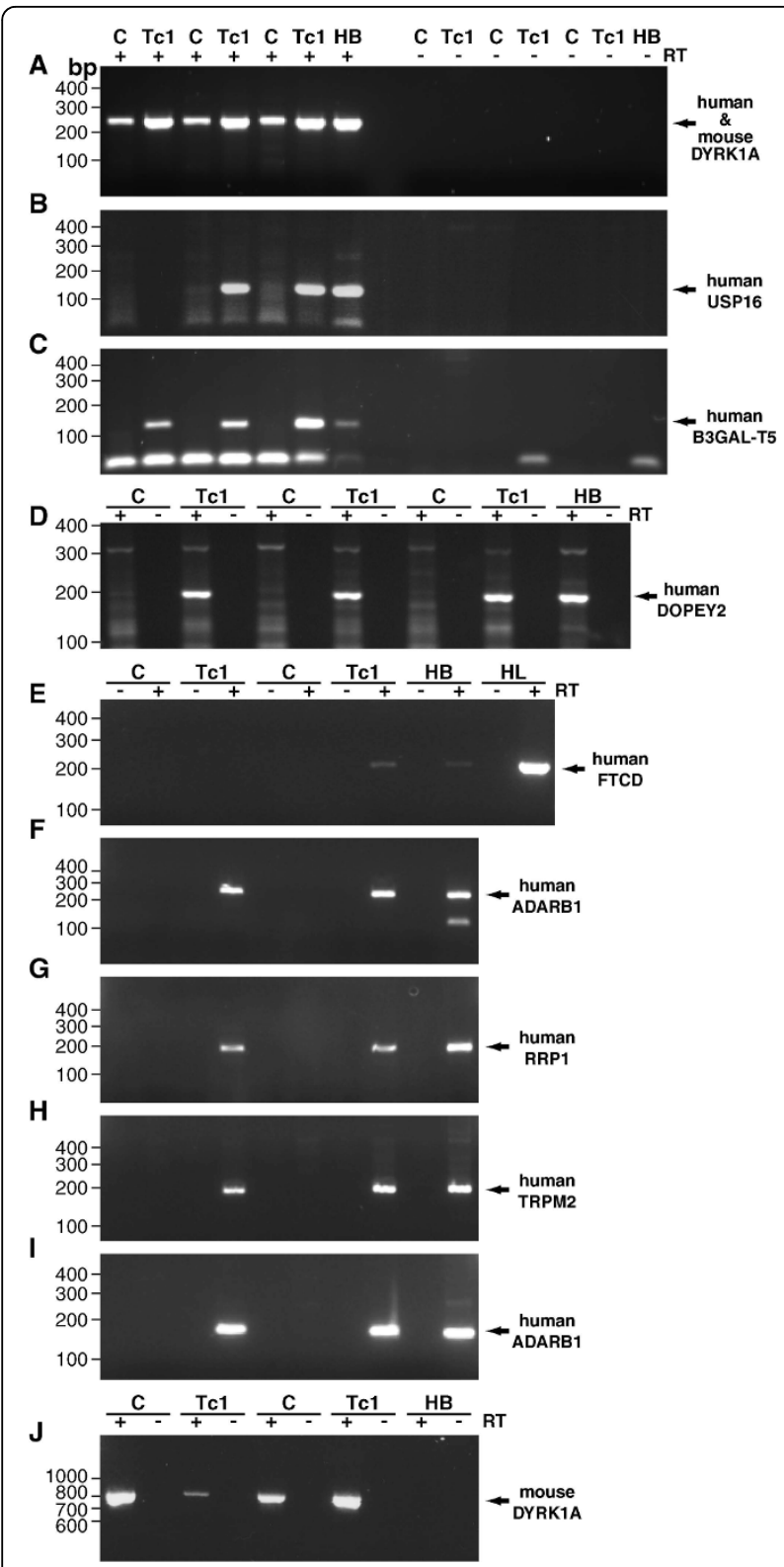

Figure 1 Expression of candidate Hsa21 genes in the Tc1 adult brain. To determine if the candidate genes were expressed, RT-PCR was undertaken using primers against (B) USP16 (129 base pair product), (C) B3GAL-T5 (138 base pair product), (D) DOPEY2 (192 base pair product), (E) FTCD (207 base pair product), (F) ADARB1primer set 1 (134 or 254 base pair product), (G) RRP1 (173 base pair product) (H) TRPM2 (181 base pair product) and (I) ADARB1- primer set 2 (156 base pair product) was undertaken. Primers against (A) human and mouse DYRK1A (235 base pair product) and (J) mouse Dyrk1a (793 base pair product) were used as controls. RNA from Tc1 adult mouse brains (TC1), non-transchromosomic littermate control adult brains (C), human adult brain ( $\mathrm{HB})$ and human adult liver $(\mathrm{HL})$ was used as indicated. therefore the $50 \mathrm{kDa}$ band detected after probing with this antibody is highly unlikely to be RRP1.

An antibody affinity purified against RRP1 peptide A (9644-A) did recognise a band consistent with the molecular weight of RRP1 in samples of both Tc1 and control brain (Figure $2 \mathrm{C}$ ). Five of the nineteen amino acids of peptide A are homologous with the mouse RRP1 protein sequence including a sequence (K*PA) with high predicted antigenicity. Therefore the antibody purified against peptide A may recognise both mouse and human RRP1 and therefore is not useful to identify Hsa 21 positive cells in the Tc1 model. An antibody affinity purified against peptide $A$ from the other rabbit (9643-B) did not consistently recognise a band corresponding to the molecular weight of RRP1 (Figure 2D). This suggests that RRP1 peptide A is not a reliable antigen for the production of rabbit polyclonal antibodies.

\section{Antibodies that did not recognise a Tc1 unique product SOD1}

Immunisation with a single SOD1 peptide generated anti-SOD1 antibodies (9638 and 9637) that recognised a Tc1 specific band on western blots of total brain protein (Figure 2E and 2F). The size of the bands recognised is consistent with the known molecular weight of the SOD1 monomer $(16 \mathrm{kDa})$. These antibodies also detected a band of a comparable molecular weight in samples of total brain proteins isolated from transgenic mice that over-express wild-type or mutant (SOD1 ${ }^{\mathrm{G} 93 \mathrm{~A}}$ ) human SOD1 and in samples of recombinant human SOD1 (wild-type or SOD1 ${ }^{\text {G93A }}$ ) (gift of Ruth Chia) (Figure $2 \mathrm{E}$ and $2 \mathrm{~F}$ ). The $16 \mathrm{kDa}$ band was not observed in samples of brain from non-transchromosomic control mice. However, after long exposures a weak band that was smaller than the predominant $16 \mathrm{kDa}$ band was detected by both 9637 and 9638 in Tc1 and control mouse brain samples. This smaller band may be mouse SOD1; thus antibody 9637 and 9638 may weakly crossreact with mouse SOD1. Moreover, these antibodies generated an intracellular staining pattern of similar intensity on Tc1 and non-transchromosomic control mice brain sections, which were either paraffinembedded or cryopreserved (Figure 3C-F, data not shown). The antibody does not recognise cells specifically in the Tc1 brain and therefore cannot be used to identify these Hsa21 positive cells in our mouse model for future studies. This result may occur because the polyclonal antibodies generated recognise non-SOD1 proteins and weakly cross-react with mouse SOD1 in both Tc1 and control brain, or that the antibodies 
Table 2 List of Hsa21 Genes and peptides used to immunise rabbits.

\begin{tabular}{|c|c|c|c|}
\hline Candidate Protein & $\begin{array}{l}\text { Molecular } \\
\text { weight of } \\
\text { protein }(\mathrm{kDa})\end{array}$ & $\begin{array}{l}\text { Peptide used to immunise rabbits } \\
\text { (protein accession numbers) }\end{array}$ & $\begin{array}{l}\text { Mean } \\
\text { antigenicity } \\
\text { index } \\
\text { (Jameson } \\
\text { and Wolf) }\end{array}$ \\
\hline $\begin{array}{l}\text { Double-stranded RNA-specific editase } \\
1 \text { (ADARB1) }\end{array}$ & 80 & $\begin{array}{l}\text { Acetyl-CNHGSLQPRPPGLLSDPS-amide (ENSP00000374512, amino acid 478- } \\
\text { 495) }\end{array}$ & 1.088889 \\
\hline \multirow[t]{2}{*}{$\begin{array}{l}\text { B-1,3-galactosyltransferase } 5 \text { (B3GAL- } \\
\text { T5) }\end{array}$} & 36 & 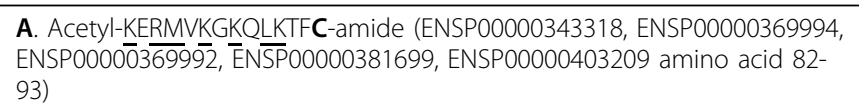 & 0.720833 \\
\hline & & $\begin{array}{l}\text { B.Acetyl-CAAETKEVDQESQRHGDI-amide (ENSP00000343318, } \\
\text { ENSP00000369994, ENSPD00000369992, ENSP00000381699, } \\
\text { ENSP00000403209, amino acid 103-119) }\end{array}$ & 1.547647 \\
\hline Protein Dopey 2 (DOPEY2) & 258 & $\begin{array}{l}\text { Acetyl-CFRPVKQRYSVRNSVS-amide (ENSP00000382104, amino acid 455- } \\
\text { 470) }\end{array}$ & 1.244375 \\
\hline \multirow[t]{2}{*}{$\begin{array}{l}\text { Ribosomal RNA processing protein } 1 \\
\text { homolog A (RRP1) }\end{array}$} & 53 & $\begin{array}{l}\text { A. Acetyl-GDALSQKRSEKPPAGSIC-amide (ENSP00000291569, amino acid } \\
\text { 257-275) }\end{array}$ & 1.745 \\
\hline & & $\begin{array}{l}\text { B. Acetyl-CGARQRRRTPRPLTSARAKA-amide (ENSP00000291569, amino acid } \\
428-446)\end{array}$ & 1.839474 \\
\hline $\begin{array}{l}\text { Transient receptor potential cation } \\
\text { channel subfamily M member } 2 \\
\text { (TRPM2) }\end{array}$ & 165,177 & $\begin{array}{l}\text { Acetyl-CSWRLQ[Abu]PFGNNDKQESL-amide (ENSP00000381023, } \\
\text { ENSP00000300481, ENSSP00000300482, ENSP00000393982, } \\
\text { ENSP00000381026, amino acid 43-59) }\end{array}$ & 1.105882 \\
\hline Superoxide dismutase 1 (SOD1) & 16 & $\begin{array}{l}\text { Acetyl-FEQKESNGPVKVWGSIC-amide (ENSP00000270142, amino acid 21-36, } \\
\text { ENSP00000374645, amino acid 6-17) }\end{array}$ & 0.9875 \\
\hline $\begin{array}{l}\text { Ubiquitin carboxyl-terminal hydrolase } \\
16 \text { (USP16) }\end{array}$ & 94 & 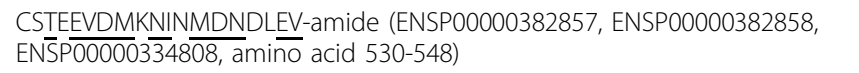 & 0.930556 \\
\hline
\end{tabular}

Added conjugating cysteine are highlighted in bold, amino acids that are only found in human sequence are underlined. Abu, abbreviation for amino-n-butyric acid, used to substitute for an internal cysteine residue.

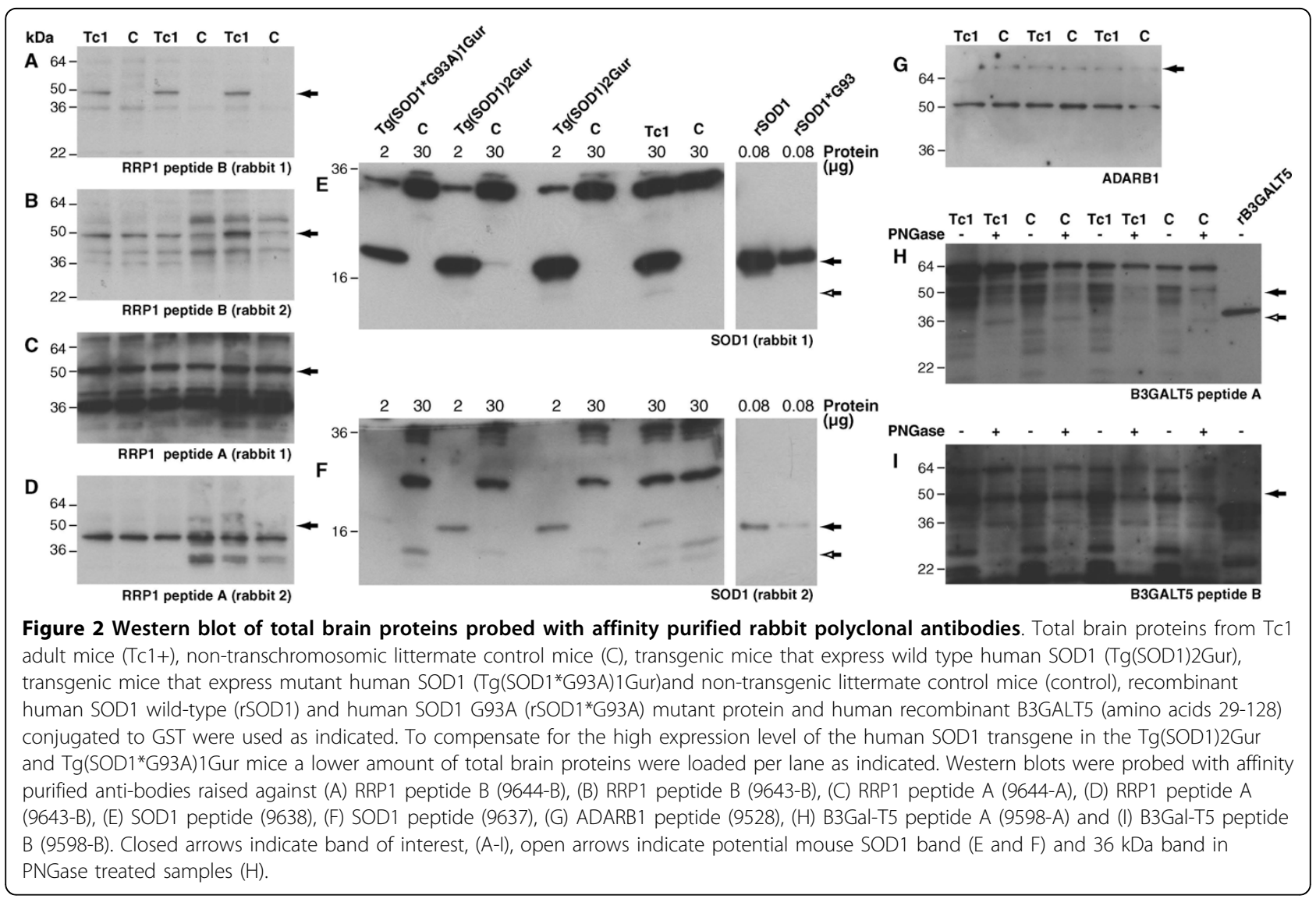



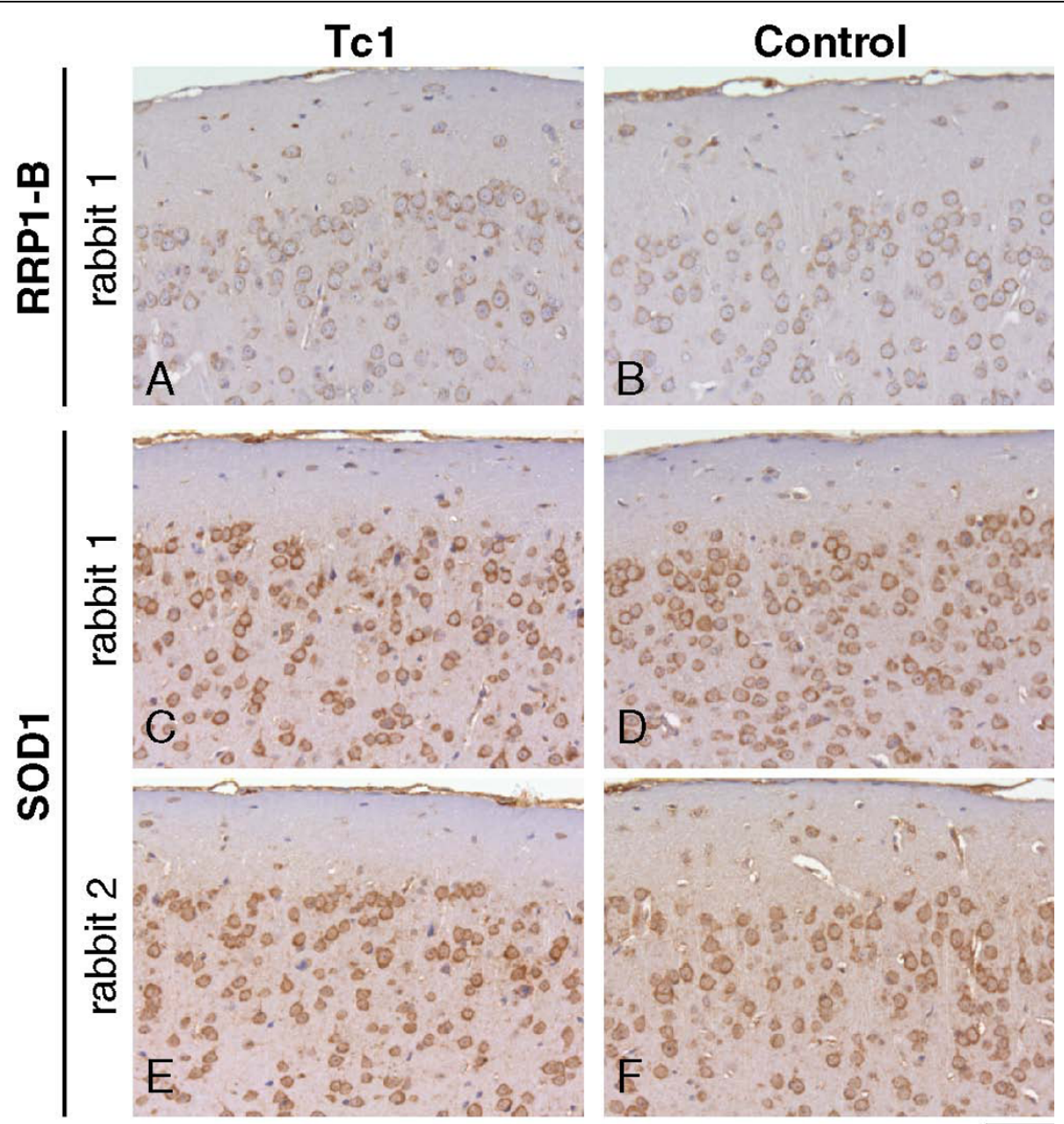

Figure 3 Affinity purified anti-RRP1 and SOD1 antibodies do not specifically label cells in the Tc1 mouse model. A similar pattern and intensity of staining is observed in adult TC1 (A, C, E) and non-transchromosomic littermate control $(B, D, F)$ cortical brain sections stained with affinity purified rabbit polyclonal antibodies generated against (A and B) RRP1 peptide B (9644-B), (C and D) SOD1 peptide (9638) and (E and F) SOD1 peptide (9637). Paraffin embedded sections were pretreated with protease prior to incubation with rabbit polyclonal antibodies, nuclei were counter-stained with haematoxylin. Scale bar $=50 \mu \mathrm{m}$.

generated only recognise denatured human SOD1. We have previously tested whether a number of commercially available anti-SOD1 antibodies specifically label cells in Tc1 brain sections and found that these antibodies were not specific (data not shown).

\section{ADARB1}

An affinity purified antibody (9528) that reacted weakly with a band consistent with the known molecular weight of the protein, $80 \mathrm{kDa}$, was isolated from one rabbit injected with the ADARB1 peptide (Figure 2G). However, this band was observed in samples of total brain proteins from both Tc1 and non-transchromosomic control mice. As ADARB1 peptide sequence used to challenge the rabbits was unique to human ADARB1 and not found in mouse, the protein recognised by this antibody is unlikely to be ADARB1. No signal consistent with the molecular weight of ADARB1 was observed when western blots of total brain proteins were probed with affinity purified antibody generated from the second rabbit (9529), which was challenged with ADARB1 peptide (data not shown).

\section{B3GALT5}

Affinity purified antibodies raised against B3GAL-T5 peptides were used to probe western blots of total brain proteins from $\mathrm{Tc} 1$ and control mice and recombinant glutathione-S-transferase (GST) tagged human B3GALT5 (amino acids 29-128, Abnova). Recombinant human B3GAL-T5 was detected using both antibodies (Figure $2 \mathrm{H}$ and $2 \mathrm{I}$ ). A predominant band of $64 \mathrm{kDa}$ and weaker bands of around $50 \mathrm{kDa}$ were detected in western blots of Tc1 and control samples probed with antibodies affinity purified against peptide A (9598-A) (Figure 2H). A 
predominant band of $50 \mathrm{kDa}$ and weaker bands of 64 , 36 and approximately $28 \mathrm{kDa}$ were detected in western blots of samples of total brain proteins from Tc1 and control mice that were probed with antibodies affinity purified against peptide B (9598-B) (Figure 2I). The molecular weight of human B3GAL-T5 is $36 \mathrm{kDa}$. However, B3GAL-T5 contains three $\mathrm{N}$-glycosylation sequences (amino acids 130, 174 and 231) that may be occupied in vivo. Indeed in COS-7 cells a variety of B3GAL-T5 glycoforms of between 37-50 kDa are detected by western blot [15]. To investigate if the protein bands detected in samples of Tc1 and control brain are glycosylated forms of B3GAL-T5 samples of Tc1 and control brain proteins were treated with PNGase F, an enzyme that cleaves protein-attached $\mathrm{N}$-linked glycans, before western blotting. De-glycosylation of endogenous proteins was confirmed by checking that the glycoprotein PrP exhibited the expected size shift after PNGase F treatment (data not shown). Enrichment of a $36 \mathrm{kDa}$ protein was observed in Tc1 and control brain samples after treatment PNGase F on western blots probed with the antibody affinity purified against peptide A (9598-A), consistent with this antibody recognising endogenous B3GAL-T5 (Figure 2H). No enrichment in a $36 \mathrm{kDa}$ band was observed in the brain samples treated with PNGase F that were probed with the antibody affinity purified against peptide B (9598-B) (Figure $2 \mathrm{I})$. This result suggests that the $50 \mathrm{kDa}$ protein recognised by antibody $9598-\mathrm{B}$ is not a glycosylated form of B3GAL-T5.

\section{DOPEY2, TRPM2 and USP16}

Affinity purified rabbit polyclonal antibodies raised against DOPEY2 and TRPM2 and USP16 peptides did not react with a band of the predicted molecular weight, in western blots of Tc1 and non-transchromosomic control total brain proteins (data not shown). In addition the pattern and intensity of staining observed in Tc1 and non-transchromosomic control paraffin-embedded or cryopreserved brain sections was similar, indicating that that these antibodies do not recognise a Hsa21 specific product (data not shown).

\section{Discussion}

In order to specifically detect cells carrying Hsa21 in our Tc1 mice, we carried out extensive literature searches of both commercial and basic research resources and were unable to find suitable antibodies that could be used on fixed tissues and primary cell cultures. Many antibodies to Hsa21 derived proteins exist, but none that we could find specifically recognised Hsa21 positive cells in Tc1 mouse brain sections and not control non-transchromosomic mouse sections. Therefore we attempted to generate Hsa21 antibodies that we could use to identify Hsa21 carrying cells in our model.
From bioinformatics analysis, we identified eight genes which were present in the Tc1 mouse and which might make suitable candidates for further analysis. One of these, FTCD, was not expressed in brain and so we generated eighteen different antibodies raised against amino-acid sequences identified from the remaining seven genes, selecting only sequences which were divergent between mouse and human, and likely to be moderately/highly antigenic.

We generated a panel of antibodies, of which one antibody (9644-B) raised against RRP1 appeared to be human specific on western blots, although proved unsuitable for immunohistochemistry and two new antibodies raised against SOD1 (9638 and 9637) that appear to preferentially recognise human SOD1 on western blots, but do not recognise Hsa21 positive cells in Tc1 brains by immunohistochemistry.

\section{Conclusion}

Having surveyed 295 genes on Hsa21 we are left with three antibodies that we can use for western blot analysis that will preferentially bind to human protein, and none that will work by immunohistochemistry. This illustrates the difficulty of making antibodies that only recognise a specific human protein but not its mouse homologue, even with extensive knowledge of the genes available, their likely antigenicity and the degree of conservation between mouse and human. We will now go on to other methods for detecting Hsa21 in tissue sections and cultured cells, and we note that the antibodies we have generated are available to interested laboratories.

\section{Methods}

\section{Animal Welfare}

Mice were housed in controlled conditions in accordance with guidance issued by the Medical Research Council in Responsibility in the Use of Animals for Medical Research (1993) and all experiments were carried out under License from the UK Home Office.

\section{DNA extraction and Genotyping}

DNA was extracted from tail tip (approximately $3 \mathrm{~mm}$ ) from all samples analysed. Tail tip is lysed overnight using Proteinase $\mathrm{K}$ digestion in nuclei lysis buffer (Promega), plus $0.12 \mathrm{M} \mathrm{EDTA}$ at $55^{\circ} \mathrm{C}$. Proteins are precipitated from the resultant lysate by addition of protein precipitation solution (Promega), DNA is then precipitated with isopropanol and resuspended in DNase free water. Tc1 mice were genotyped using PCR (Tc1 specific primers f: 5'GGTTTGAGGGAACACAAAGCTTAACTCCCA-3' r: 5'ACAGAGCTACAGCCTCTGACACTATGAACT-3', control primers f: 5'-TTACGTCCATCGTGGACAGCAT3' r: 5'-TGGGCTGGGTGTTAGTCTTAT-3'). Tc1 mice 
were taken from a colony maintained by mating Tc1 females to F1(129S8 × C57BL/6) males. Both SOD1 transgenics were taken from colonies maintained by crossing male transgenics to female C57BL6/J (Jackson Laboratories, Bar Harbour). SOD1 transgenic mice (Tg(SOD1) 2Gur, Jackson and $\mathrm{Tg}$ (SOD1*G93A)1Gur; Jackson Laboratories, Bar Harbour) were genotyped by PCR (SOD1 specific primers f: 5'-CATCAGCCC TAATCCATCTGA-3' r: 5'-CGCGACTAACAATCAAAGTGA-3', control primers f: 5'-CTAGGCCACAGAATTGAAAGATCT-3' r: 5'GTAGGTGGAAATTCTAGCATCATC-3').

\section{RNA extraction and RT-PCR}

RNA was extracted from whole brains from 6-10 week old Tc1 and age and sex matched non-transchromosomic controls. Total RNA was extracted using TRIzol reagent (Invitrogen), precipitated as per manufactures instructions and resuspended in DNase-free water. Amounts of RNA were equalised and cDNA was generated using a standard reverse-transcription protocol using random primers (Promega), Superscript II (Invitrogen), First Strand Buffer (Invitrogen) and dNTPs (Promega). PCR using primers which amplify a PCR product from both mouse Dyrk1A and human DYKR1A (f: 5'-GGAGAGACTTCAGCATGCAAAC-3' r: 5'-GCTGGGTCACGGAAGGT TTG-3') or mouse DYRK1A (f: 5'-CAAGAAAACAGCTGATGAAGG-3' r: 5'-AGCCCCTTGTCTCATCGC-3') were used to check CDNA. PCR using primers designed to raised a product against human but not mouse FTCD (f: 5'GAATGCGTCCCCAACTTTTCG-3' r: 5'-GTCGATAAGTCGGGAAGCTAC-3'), USP16 (f: 5'-AAGCCTTCAGTTTGGCTG-3' r: 5'-GTCCAAACTAAGAACCAGAC3'), DOPEY2 (f: 5'-ACCTGAGGTACTCCTTGTTG-3' r: 5'CCAGGAGAGGAAATAACCCG-3'), TRPM2 (f: 5'-GTTC GTGGATTCCTGAAAAC-3' r: 5'-TCCAAGTGCTGCTCATGC-3' and f: 5'-TGGCCGTCAGCGTCCACTTC-3' r: 5'TAGTGAGCCCCGAACTCAGC-3'), B3GAL-T5 (f: 5'-CACTGTGGCTTTAGCTTTCAAAC-3' r: 5'-GGATTTAGACTGTACATGC-3'), ADARB1 (f: 5'-TTTAGGCTGAAGGAGAATGTC-3' r: 5'-CCTCTTGCTTTACGATTTGGG-3' and $\mathrm{f}$ : 5'-GTCTCGCTCTTACACCCAG-3' r: 5'-CCTC TTGCTTTACGATTTGGG-3') and RRP1 (f: $5^{\prime}$-TCCCTGAAGATGAGATCCCAG-3' $r$ : 5'-TACACCCCTCCTCCTGCTC$3^{\prime}$ ) were used to check the expression of these genes from Hsa21.

\section{Western blotting}

Whole brain from Tc1, $\mathrm{Tg}$ (SOD1)2Gur, Tg (SOD1*G93A)1Gur and aged and sex matched control non-transgenic mice was homogenized in 9 volumes of RIPA Buffer (150 mM sodium chloride, $50 \mathrm{mM}$ Tris, $1 \%$ NP-40, $0.5 \%$ sodium deoxycholate, $0.1 \%$ sodium dodecyl sulfate) or phosphate buffered saline plus complete protease inhibitors (PBS) (Roche Applied Science) by mechanical disruption using a dounce homogenizer.
Total protein content was determined using the DC protein Assay (Biorad). Samples that were homogenized

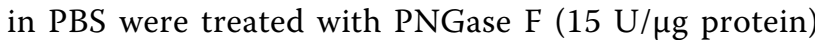
(New England Biolabs) for 3 hours shaking at $37^{\circ} \mathrm{C}$ to cleave N-linked glycans. The resultant total brain protein and recombinant protein samples were denatured in SDS denaturing buffer (Invitrogen) and $\beta$-mercaptoethanol for 10 minutes at $100^{\circ} \mathrm{C}$, prior to separation by SDS-PAGE gel electrophoresis using precast $16 \%$ or 4-20\% Tris-glycine gels (Invitrogen). Proteins were transferred to PVDF membrane prior to blocking in 5\% milk PBS for 1 hour before incubating over-night with primary antibody at $4^{\circ} \mathrm{C}$. Membranes were then incubated with an anti-rabbit secondary antibody (SigmaAldrich) conjugated to alkaline phosphatase prior to development with CDP-Star (Roche Applied Sciences) and exposure to X-ray film. See-Blue plus 2 (Invitrogen) was used as a molecular weight marker.

\section{Immunohistochemistry}

Whole Tc1 and non-transchromosomic control mouse brain was fixed by immersion in $10 \%$ buffered formal saline (Pioneer Research Chemicals). Following further washing for $24 \mathrm{hr}$ in $10 \%$ buffered formal saline, tissue samples were processed and embedded in paraffin wax. Sections were cut at a thickness of $4 \mu \mathrm{m}$. Alternatively brains were protected in Tissue-Tek (Siemens Healthcare Diagnostics) and frozen by immersion in isopentane chilled with liquid nitrogen. Frozen sections were cut at a thickness of $10 \mu \mathrm{m}$ on a cryostat and air dried prior to staining. Paraffin-embedded sections were pretreated by protease digestion. Staining with the rabbit polyclonal antibodies was undertaken using a Ventana automated immunohistochemical staining machine (Ventana Medical Systems, Tuscon, AZ, USA) as described previously [16]. A biotinylated-anti-rabbit IgG secondary antibody ( $i$ View SA-HRP, Ventana Medical Systems) was used before development with 3'3 diaminobenzidine tetrachloride as the chromogen (iView DAB, Ventana Medical Systems). Haematoxylin was used as the counter-stain.

\section{Acknowledgements \\ We thank Ray Young for help with preparation of the figures and Ruth Chia for recombinant SOD1 proteins. VLJT is funded by the UK Medical Research Council, the AnEUploidy grant from Framework Programme 6 from the European Union Commission, the Leukaemia Research Fund and the Wellcome Trust; FKW, OS and EMCF are funded by the UK Medical Research Council, the Wellcome Trust, the AnEUploidy grant from Framework Programme 6 from the European Union Commission and the Fidelity Foundation. These funding bodies had no role in the design of this study or the decision to publish these data.}

\section{Author details}

${ }^{1}$ Department of Neurodegenerative Disease, UCL Institute of Neurology, Queen Square, London WC1N 3BG, UK. ${ }^{2}$ MRC National Institute for Medical Research, The Ridgeway, Mill Hill, London NW7 1AA, UK. 


\section{Authors' contributions}

FW carried out the bioinformatic searches, immunohistochemistry and some RT-PCRs and western blots, analysed the data and assisted in drafting the manuscript. OS carried out the some RT-PCRs and western blots and assisted in drafting the manuscript. $J \mathrm{~L}$ and SB assisted with $\mathrm{HC}$ data collection and analysis. EF and VT conceived the study, and participated in its design and coordination and helped to draft the manuscript. All authors read and approved the final manuscript

\section{Competing interests}

The authors declare that they have no competing interests.

Received: 15 March 2010 Accepted: 20 August 2010

Published: 20 August 2010

\section{References}

1. Wiseman FK, Alford KA, Tybulewicz VL, Fisher EM: Down syndrome-recent progress and future prospects. Hum Mol Genet 2009, 18:R75-R83.

2. O'Doherty A, Ruf S, Mulligan C, Hildreth V, Errington ML, Cooke S, Sesay A, Modino S, Vanes L, Hernandez D, et al: An aneuploid mouse strain carrying human chromosome 21 with down syndrome phenotypes. Science 2005, 309:2033-2037.

3. Galante M, Jani H, Vanes L, Daniel H, Fisher EM, Tybulewicz VL, Bliss TV, Morice E: Impairments in motor coordination without major changes in cerebellar plasticity in the Tc1 mouse model of Down syndrome. Hum Mol Genet 2009, 18:1449-1463.

4. Morice E, Andreae LC, Cooke SF, Vanes L, Fisher EM, Tybulewicz VL, Bliss TV: Preservation of long-term memory and synaptic plasticity despite shortterm impairments in the Tc1 mouse model of Down syndrome. Learn Mem 2008, 15:492-500

5. Reynolds LE, Watson AR, Baker M, Jones TA, D'Amico G, Robinson SD, Joffre C, Garrido-Urbani S, Rodriguez-Manzaneque JC, Martino-Echarri E, et al: Tumour angiogenesis is reduced in the Tc1 mouse model of Down's syndrome. Nature 2010, 465:813-817.

6. Stoll C, Alembik Y, Dott B, Roth MP: Study of Down syndrome in 238,942 consecutive births. Ann Genet 1998, 41:44-51.

7. Devlin L, Morrison PJ: Mosaic Down's syndrome prevalence in a complete population study. Arch Dis Child 2004, 89:1177-1178.

8. Papavassiliou P, York TP, Gursoy N, Hill G, Nicely LV, Sundaram U, McClain A, Aggen SH, Eaves $L$, Riley $B$, et al: The phenotype of persons having mosaicism for trisomy 21/Down syndrome reflects the percentage of trisomic cells present in different tissues. Am J Med Genet A 2009, 149A:573-583.

9. Kingsbury MA, Friedman B, McConnell MJ, Rehen SK, Yang AH, Kaushal D, Chun J: Aneuploid neurons are functionally active and integrated into brain circuitry. Proc Natl Acad Sci USA 2005, 102:6143-6147.

10. Rehen SK, Yung YC, McCreight MP, Kaushal D, Yang AH, Almeida BS, Kingsbury MA, Cabral KM, McConnell MJ, Anliker B, et al: Constitutional aneuploidy in the normal human brain. J Neurosci 2005, 25:2176-2180.

11. Kingsbury MA, Yung YC, Peterson SE, Westra JW, Chun J: Aneuploidy in the normal and diseased brain. Cell Mol Life Sci 2006, 63:2626-2641.

12. Jameson $B A$, Wolf $H$ : The antigenic index: a novel algorithm for predicting antigenic determinants. Comput Appl Biosci 1988, 4:181-186.

13. Claros MG, Vincens $P$ : Computational method to predict mitochondrially imported proteins and their targeting sequences. Eur J Biochem 1996, 241:779-786

14. Emanuelsson $\mathrm{O}$, Brunak S, von Heijne G, Nielsen H: Locating proteins in the cell using TargetP, SignalP and related tools. Nat Protoc 2007, 2:953-971.

15. Seko A, Kataoka F, Aoki D, Sakamoto M, Nakamura T, Hatae M, Yonezawa S, Yamashita K: Beta1,3-galactosyltransferases-4/5 are novel tumor markers for gynecological cancers. Tumour Biol 2009, 30:43-50.

16. Wadsworth JD, Powell C, Beck JA, Joiner S, Linehan JM, Brandner S, Mead S, Collinge J: Molecular diagnosis of human prion disease. Methods Mol Biol 2008, 459:197-227.

17. Otterson GA, Flynn GC, Kratzke RA, Coxon A, Johnston PG, Kaye FJ: Stch encodes the 'ATPase core' of a microsomal stress 70 protein. EMBO $\mathrm{J}$ 1994, 13:1216-1225.

18. Sultan M, Piccini I, Balzereit D, Herwig R, Saran NG, Lehrach H, Reeves RH, Yaspo ML: Gene expression variation in Down's syndrome mice allows prioritization of candidate genes. Genome Biol 2007, 8:R91.
19. Valero R, Marfany G, Gonzalez-Angulo O, Gonzalez-Gonzalez G, Puelles L, Gonzalez-Duarte R: USP25, a novel gene encoding a deubiquitinating enzyme, is located in the gene-poor region 21q11.2. Genomics 1999, 62:395-405.

20. Valero R, Bayes M, Francisca Sanchez-Font M, Gonzalez-Angulo O, GonzalezDuarte R, Marfany G: Characterization of alternatively spliced products and tissue-specific isoforms of USP28 and USP25. Genome Biol 2001, 2: RESEARCH0043.

21. Lockstone HE, Harris LW, Swatton JE, Wayland MT, Holland AJ, Bahn S: Gene expression profiling in the adult Down syndrome brain. Genomics 2007, 90:647-660.

22. Palmeri D, van Zante A, Huang CC, Hemmerich S, Rosen SD: Vascular endothelial junction-associated molecule, a novel member of the immunoglobulin superfamily, is localized to intercellular boundaries of endothelial cells. J Biol Chem 2000, 275:19139-19145.

23. Aurrand-Lions M, Johnson-Leger C, Wong C, Du PL, Imhof BA: Heterogeneity of endothelial junctions is reflected by differential expression and specific subcellular localization of the three JAM family members. Blood 2001, 98:3699-3707.

24. McCulloch DR, Le Goff C, Bhatt S, Dixon LJ, Sandy JD, Apte SS: Adamts5, the gene encoding a proteoglycan-degrading metalloprotease, is expressed by specific cell lineages during mouse embryonic development and in adult tissues. Gene Expr Patterns 2009, 9:314-323.

25. Gunther W, Skaftnesmo KO, Arnold H, Bjerkvig R, Terzis AJ: Distribution patterns of the anti-angiogenic protein ADAMTS-1 during rat development. Acta Histochem 2005, 107:121-131.

26. Kubota $H$, Hynes $G$, Willison $K$ : The eighth Cct gene, Cctq, encoding the theta subunit of the cytosolic chaperonin containing TCP-1. Gene 1995, 154:231-236.

27. Kubota H, Yokota S, Yanagi H, Yura T: Structures and co-regulated expression of the genes encoding mouse cytosolic chaperonin CCT subunits. Eur J Biochem 1999, 262:492-500.

28. Sakoda E, Igarashi K, Sun J, Kurisu K, Tashiro S: Regulation of heme oxygenase- 1 by transcription factor Bach1 in the mouse brain. Neurosci Lett 2008, 440:160-165.

29. Choi KH, Zepp ME, Higgs BW, Weickert CS, Webster MJ: Expression profiles of schizophrenia susceptibility genes during human prefrontal cortical development. J Psychiatry Neurosci 2009, 34:450-458.

30. Mozhui K, Karlsson RM, Kash TL, Ihne J, Norcross M, Patel S, Farrell MR, Hill EE, Graybeal C, Martin KP, et al: Strain differences in stress responsivity are associated with divergent amygdala gene expression and glutamate-mediated neuronal excitability. J Neurosci 2010, 30:5357-5367.

31. Gulesserian T, Seidl R, Hardmeier R, Cairns N, Lubec G: Superoxide dismutase SOD1, encoded on chromosome 21, but not SOD2 is overexpressed in brains of patients with Down syndrome. J Investig Med 2001, 49:41-46

32. de Haan JB, Newman JD, Kola I: Cu/Zn superoxide dismutase mRNA and enzyme activity, and susceptibility to lipid peroxidation, increases with aging in murine brains. Brain Res Mol Brain Res 1992, 13:179-187.

33. Shin JH, Krapfenbauer K, Lubec G: Mass-spectrometrical analysis of proteins encoded on chromosome 21 in human fetal brain. Amino Acids 2006, 31:435-447.

34. Tobin JE, Cui J, Wilk JB, Latourelle JC, Laramie JM, McKee AC, Guttman M, Karamohamed S, DeStefano AL, Myers RH: Sepiapterin reductase expression is increased in Parkinson's disease brain tissue. Brain Res 2007, 1139:42-47.

35. Rachidi M, Lopes C, Delezoide AL, Delabar JM: C21orf5, a human candidate gene for brain abnormalities and mental retardation in Down syndrome. Cytogenet Genome Res 2006, 112:16-22.

36. Rachidi M, Lopes C, Costantine M, Delabar JM: C21 orf5, a new member of Dopey family involved in morphogenesis, could participate in neurological alterations and mental retardation in Down syndrome. DNA Res 2005, 12:203-210.

37. Rachidi M, Delezoide AL, Delabar JM, Lopes C: A quantitative assessment of gene expression (QAGE) reveals differential overexpression of DOPEY2, a candidate gene for mental retardation, in Down syndrome brain regions. Int J Dev Neurosci 2009, 27:393-398.

38. Lopes C, Chettouh Z, Delabar JM, Rachidi M: The differentially expressed C21 orf5 gene in the medial temporal-lobe system could play a role in mental retardation in Down syndrome and transgenic mice. Biochem Biophys Res Commun 2003, 305:915-924. 
39. Metz RP, Kwak Hl, Gustafson T, Laffin B, Porter WW: Differential transcriptional regulation by mouse single-minded 2s. J Biol Chem 2006, 281:10839-10848.

40. Ema M, Ikegami S, Hosoya T, Mimura J, Ohtani H, Nakao K, Inokuchi K, Katsuki M, Fujii-Kuriyama Y: Mild impairment of learning and memory in mice overexpressing the mSim2 gene located on chromosome 16: an animal model of Down's syndrome. Hum Mol Genet 1999, 8:1409-1415.

41. Fan CM, Kuwana E, Bulfone A, Fletcher CF, Copeland NG, Jenkins NA, Crews S, Martinez S, Puelles L, Rubenstein JL, et al: Expression patterns of two murine homologs of Drosophila single-minded suggest possible roles in embryonic patterning and in the pathogenesis of Down syndrome. Mol Cell Neurosci 1996, 7:1-16.

42. Nakamura A, Hattori M, Sakaki Y: Isolation of a novel human gene from the Down syndrome critical region of chromosome 21q22.2. J Biochem 1997, 122:872-877

43. Ferrer I, Barrachina M, Puig B, Martinez dL, Marti E, Avila J, Dierssen M: Constitutive Dyrk1A is abnormally expressed in Alzheimer disease, Down syndrome, Pick disease, and related transgenic models. Neurobiol Dis 2005, 20:392-400.

44. Marti E, Altafaj X, Dierssen M, de la LS, Fotaki V, Alvarez M, Perez-Riba M, Ferrer I, Estivill X: Dyrk1A expression pattern supports specific roles of this kinase in the adult central nervous system. Brain Res 2003, 964:250-263.

45. Wegiel J, Kuchna I, Nowicki K, Frackowiak J, Dowjat K, Silverman WP, Reisberg B, Deleon M, Wisniewski T, Adayev T, et al: Cell type- and brain structure-specific patterns of distribution of minibrain kinase in human brain. Brain Res 2004, 1010:69-80.

46. Harashima C, Jacobowitz DM, Witta J, Borke RC, Best TK, Siarey RJ, Galdzicki Z: Abnormal expression of the G-protein-activated inwardly rectifying potassium channel 2 (GIRK2) in hippocampus, frontal cortex and substantia nigra of Ts65Dn mouse: a model of Down syndrome. $J$ Comp Neurol 2006, 494:815-833.

47. Schein JC, Hunter DD, Roffler-Tarlov S: Girk2 expression in the ventral midbrain, cerebellum, and olfactory bulb and its relationship to the murine mutation weaver. Dev Biol 1998, 204:432-450.

48. Wei J, Hodes ME, Piva R, Feng Y, Wang Y, Ghetti B, Dlouhy SR: Characterization of murine Girk2 transcript isoforms: structure and differential expression. Genomics 1998, 51:379-390.

49. Greber-Platzer S, Schatzmann-Turhani D, Cairns N, Balcz B, Lubec G: Expression of the transcription factor ETS2 in brain of patients with Down syndrome-evidence against the overexpression-gene dosage hypothesis. J Neural Transm Suppl 1999, 57:269-281.

50. Vidal-Taboada JM, Lu A, Pique M, Pons G, Gil J, Oliva R: Down syndrome critical region gene 2: expression during mouse development and in human cell lines indicates a function related to cell proliferation. Biochem Biophys Res Commun 2000, 272:156-163.

51. Dunn CA, Medstrand $P$, Mager DL: An endogenous retroviral long terminal repeat is the dominant promoter for human beta1,3galactosyltransferase 5 in the colon. Proc Natl Acad Sci USA 2003, 100:12841-12846.

52. Ziai MR, Sangameswaran L, Hempstead JL, Danho W, Morgan Jl: An immunochemical analysis of the distribution of a brain-specific polypeptide, PEP-19. J Neurochem 1988, 51:1771-1776.

53. Ziai R, Pan YC, Hulmes JD, Sangameswaran L, Morgan Jl: Isolation, sequence, and developmental profile of a brain-specific polypeptide, PEP-19. Proc Natl Acad Sci USA 1986, 83:8420-8423.

54. Utal AK, Stopka AL, Roy M, Coleman PD: PEP-19 immunohistochemistry defines the basal ganglia and associated structures in the adult human brain, and is dramatically reduced in Huntington's disease. Neuroscience 1998, 86:1055-1063.

55. Saito Y, Oka A, Mizuguchi M, Motonaga K, Mori Y, Becker LE, Arima K, Miyauchi J, Takashima S: The developmental and aging changes of Down's syndrome cell adhesion molecule expression in normal and Down's syndrome brains. Acta Neuropathol 2000, 100:654-664.

56. Barlow GM, Chen XN, Shi ZY, Lyons GE, Kurnit DM, Celle L, Spinner NB, Zackai E, Pettenati MJ, Van Riper AJ, et al: Down syndrome congenital heart disease: a narrowed region and a candidate gene. Genet Med 2001 3:91-101.

57. Bennett BD, Babu-Khan S, Loeloff R, Louis JC, Curran E, Citron M, Vassar R: Expression analysis of BACE2 in brain and peripheral tissues. $J$ Biol Chem 2000, 275:20647-20651.
58. Hussain I, Powell DJ, Howlett DR, Chapman GA, Gilmour L, Murdock PR, Tew DG, Meek TD, Chapman C, Schneider K, et al: ASP1 (BACE2) cleaves the amyloid precursor protein at the beta-secretase site. Mol Cell Neurosci 2000, 16:609-619.

59. Barbiero L, Benussi L, Ghidoni R, Alberici A, Russo C, Schettini G, Pagano SF, Parati EA, Mazzoli F, Nicosia F, et al: BACE-2 is overexpressed in Down's syndrome. Exp Neurol 2003, 182:335-345.

60. Motonaga K, Itoh M, Becker LE, Goto Y, Takashima S: Elevated expression of beta-site amyloid precursor protein cleaving enzyme 2 in brains of patients with Down syndrome. Neurosci Lett 2002, 326:64-66.

61. Di Schiavi E, Riano E, Heye B, Bazzicalupo P, Rugarli El: UMODL1/Olfactorin is an extracellular membrane-bound molecule with a restricted spatial expression in olfactory and vomeronasal neurons. Eur J Neurosci 2005, 21:3291-3300

62. Tachikawa M, Watanabe M, Hori S, Fukaya M, Ohtsuki S, Asashima T, Terasaki T: Distinct spatio-temporal expression of ABCA and ABCG transporters in the developing and adult mouse brain. J Neurochem 2005, 95:294-304.

63. Tarr PT, Edwards PA: ABCG1 and ABCG4 are coexpressed in neurons and astrocytes of the CNS and regulate cholesterol homeostasis through SREBP-2. J Lipid Res 2008, 49:169-182.

64. Michaud J, Kudoh J, Berry A, Bonne-Tamir B, Lalioti MD, Rossier C, Shibuya K, Kawasaki K, Asakawa S, Minoshima S, et al: Isolation and characterization of a human chromosome 21q22.3 gene (WDR4) and its mouse homologue that code for a WD-repeat protein. Genomics 2000, 68:71-79.

65. Chen $H$, Rossier C, Nakamura $Y$, Lynn A, Chakravarti A, Antonarakis SE: Cloning of a novel homeobox-containing gene, PKNOX1, and mapping to human chromosome 21q22.3. Genomics 1997, 41:193-200.

66. Ferretti E, Schulz H, Talarico D, Blasi F, Berthelsen J: The PBX-regulating protein PREP1 is present in different PBX-complexed forms in mouse. Mech Dev 1999, 83:53-64.

67. Enokido Y, Suzuki E, Iwasawa K, Namekata K, Okazawa H, Kimura H: Cystathionine beta-synthase, a key enzyme for homocysteine metabolism, is preferentially expressed in the radial glia/astrocyte lineage of developing mouse CNS. FASEB J 2005, 19:1854-1856.

68. Pacheco TR, Gomes AQ, Barbosa-Morais NL, Benes V, Ansorge W, Wollerton M, Smith CW, Valcarcel J, Carmo-Fonseca M: Diversity of vertebrate splicing factor U2AF35: identification of alternatively spliced U2AF1 mRNAS. J Biol Chem 2004, 279:27039-27049.

69. Brannvall $K$, Hjelm H, Korhonen L, Lahtinen U, Lehesjoki AE, Lindholm D: Cystatin-B is expressed by neural stem cells and by differentiated neurons and astrocytes. Biochem Biophys Res Commun 2003, 308:369-374.

70. Jansen E, Meulemans SM, Orlans IC, Van de Ven WJ: The NNP-1 gene (D21S2056E), which encodes a novel nuclear protein, maps in close proximity to the cystatin $B$ gene within the EPM1 and APECED critical region on 21q22.3. Genomics 1997, 42:336-341.

71. Lu B, Jiang YJ, Zhou Y, Xu FY, Hatch GM, Choy PC: Cloning and characterization of murine 1-acyl-sn-glycerol 3-phosphate acyltransferases and their regulation by PPARalpha in murine heart. Biochem J 2005, 385:469-477.

72. Yamakawa $\mathrm{K}$, Gao DQ, Korenberg JR: A periodic tryptophan protein 2 gene homologue (PWP2H) in the candidate region of progressive myoclonus epilepsy on 21q22.3. Cytogenet Cell Genet 1996, 74:140-145.

73. Levanon D, Danciger E, Dafni N, Bernstein Y, Elson A, Moens W, Brandeis M, Groner $Y$ : The primary structure of human liver type phosphofructokinase and its comparison with other types of PFK. DNA $1989,8: 733-743$

74. Nagamine K, Kudoh J, Minoshima S, Kawasaki K, Asakawa S, Ito F, Shimizu N: Molecular cloning of a novel putative Ca2+ channel protein (TRPC7) highly expressed in brain. Genomics 1998, 54:124-131.

75. Uemura T, Kudoh J, Noda S, Kanba S, Shimizu N: Characterization of human and mouse TRPM2 genes: identification of a novel N-terminal truncated protein specifically expressed in human striatum. Biochem Biophys Res Commun 2005, 328:1232-1243.

76. Fonfria E, Murdock PR, Cusdin FS, Benham CD, Kelsell RE, McNulty S: Tissue distribution profiles of the human TRPM cation channel family. J Recept Signal Transduct Res 2006, 26:159-178.

77. Hill K, Tigue NJ, Kelsell RE, Benham CD, McNulty S, Schaefer M, Randall AD: Characterisation of recombinant rat TRPM2 and a TRPM2-like 
conductance in cultured rat striatal neurones. Neuropharmacology 2006, 50:89-97.

78. Boelaert K, Tannahill LA, Bulmer JN, Kachilele S, Chan SY, Kim D, Gittoes NJ, Franklyn JA, Kilby MD, McCabe CJ: A potential role for PTTG/securin in the developing human fetal brain. FASEB J 2003, 17:1631-1639.

79. Melcher T, Maas S, Herb A, Sprengel R, Higuchi M, Seeburg PH: RED2, a brain-specific member of the RNA-specific adenosine deaminase family. J Biol Chem 1996, 271:31795-31798.

80. Gerber A, O'Connell MA, Keller W: Two forms of human double-stranded RNA-specific editase 1 (hRED1) generated by the insertion of an Alu cassette. RNA 1997, 3:453-463.

81. O'Connell MA, Gerber A, Keller W: Purification of human double-stranded RNA-specific editase 1 (hRED1) involved in editing of brain glutamate receptor B pre-mRNA. J Biol Chem 1997, 272:473-478.

82. Mittaz L, Scott HS, Rossier C, Seeburg PH, Higuchi M, Antonarakis SE: Cloning of a human RNA editing deaminase (ADARB1) of glutamate receptors that maps to chromosome 21q22.3. Genomics 1997, 41:210-217.

83. Cheon MS, Bajo M, Kim SH, Claudio JO, Stewart AK, Patterson D, Kruger WD, Kondoh H, Lubec G: Protein levels of genes encoded on chromosome 21 in fetal Down syndrome brain: challenging the gene dosage effect hypothesis (Part II). Amino Acids 2003, 24:119-125.

84. Hagiwara H, Tajika Y, Matsuzaki T, Suzuki T, Aoki T, Takata K: Localization of Golgi $58 \mathrm{~K}$ protein (formiminotransferase cyclodeaminase) to the centrosome. Histochem Cell Biol 2006, 126:251-259.

85. Vives $\mathrm{V}$, Alonso $\mathrm{G}$, Solal $A C$, Joubert $\mathrm{D}$, Legraverend $\mathrm{C}$ : Visualization of S100B-positive neurons and glia in the central nervous system of EGFP transgenic mice. J Comp Neurol 2003, 457:404-419.

86. Scott HS, Antonarakis SE, Lalioti MD, Rossier C, Silver PA, Henry MF: Identification and characterization of two putative human arginine methyltransferases (HRMT1L1 and HRMT1L2). Genomics 1998, 48:330-340.

doi:10.1186/1477-5751-9-7

Cite this article as: Wiseman et al:: Generation of a panel of antibodies against proteins encoded on human chromosome 21. Journal of Negative Results in BioMedicine 2010 9:7.

\section{Submit your next manuscript to BioMed Central and take full advantage of:}

- Convenient online submission

- Thorough peer review

- No space constraints or color figure charges

- Immediate publication on acceptance

- Inclusion in PubMed, CAS, Scopus and Google Scholar

- Research which is freely available for redistribution

Submit your manuscript at www.biomedcentral.com/submit
Biomed Central 